\title{
Insights into biomethane production and microbial community succession during semi-continuous anaerobic digestion of waste cooking oil under different organic loading rates
}

\author{
Jing He* ${ }^{*}$, Xing Wang, Xiao-bo Yin, Qiang Li, Xia Li, Yun-fei Zhang and Yu Deng*
}

\begin{abstract}
High content of lipids in food waste could restrict digestion rate and give rise to the accumulation of long chain fatty acids in anaerobic digester. In the present study, using waste cooking oil skimmed from food waste as the sole carbon source, the effect of organic loading rate (OLR) on the methane production and microbial community dynamics were well investigated. Results showed that stable biomethane production was obtained at an organic loading rate of 0.5$1.5 \mathrm{~g} \mathrm{VS} \mathrm{L}^{-1}$ days ${ }^{-1}$. The specific biogas/methane yield values at OLR of 1.0 were $1.44 \pm 0.15$ and $0.98 \pm 0.11 \mathrm{~L} \mathrm{~g} \mathrm{VS}^{-1}$, respectively. The amplicon pyrosequencing revealed the distinct microbial succession in waste cooking oil AD reactors. Acetoclastic methanogens belonging to the genus Methanosaeta were the most dominant archaea, while the genera Syntrophomona, Anaerovibrio and Synergistaceae were the most common bacteria during AD process. Furthermore, redundancy analysis indicated that OLR showed more significant effect on the bacterial communities than that of archaeal communities. Additionally, whether the OLR of lipids increased had slight influence on the acetate fermentation pathway.
\end{abstract}

Keywords: Microbial community, Anaerobic digestion, Waste cooking oil, Biomethane, Organic loading rate

\section{Introduction}

It was estimated that annual amount of food waste (FW) come up to 36.4 and 89 million tons in USA and E.U., respectively (Agency et al. 2012; Lin et al. 2013). Approximate 60 million tons annually in China (Meng et al. 2014), including 6 million tons of waste cooking oil. Among the various proposed methods to alleviate these problems, anaerobic digestion (AD) has been considered as the waste-to-energy technology and has been performed well for treating food waste and waste cooking oil (Dasgupta and Mondal 2012; Kim et al. 2008).

*Correspondence: hejing@caas.cn; dengyu@caas.cn

Key Laboratory of Rural Renewable Energy Development and Application of the Ministry of Agriculture, Biogas Institute of Ministry of Agriculture, No. 13, Section 4, Renmin South Road, Chengdu 610041, People's Republic of China
Food waste contain three fractions including carbohydrates, proteins and oils with the different biodegradability order of carbohydrates $>$ proteins $>$ lipids (Christ et al. 2000), which means that carbohydrates and protein can be degraded and fermented faster than that of lipids. Hence, lipids degradation is the crucial step in the process of FW anaerobic digestion. High content of lipids in FW could not only impeded digestion rate of FW, but also result in the accumulation of residue in anaerobic digester (Sun et al. 2014; Zhang et al. 2013). Therefore, lipids degradation is critical for effective conversion of FW to biogas.

Lipids have been considered to be a good feedstock for the production of renewable energy at an industrial level. Furthermore, these lipids possess high methane production potential, a factor that may be harnessed for production of alternative fuels through anaerobic digestion. 
Studies have revealed that $\mathrm{AD}$ reactors can convert around $63-98 \%$ of fats, oils and grease (FOG) into biogas (Davidsson et al. 2008; Luostarinen et al. 2009). During AD process, the lipids are hydrolyzed to produce glycerol and long-chain fatty acids (LCFA) (Hanaki et al. 1981), which were further degraded through the $\beta$-oxidation pathway (Angelidaki and Ahring 1992; Cirne et al. 2007). The bacterial species responsible for the syntrophic $\beta$-oxidation of LCFA in AD reactors belong to two families, Syntrophomonadaceae and Syntrophaceae (McInerney 1992; Jackson et al. 1999; Hatamoto et al. 2007; Sousa et al. 2007a, b; Wu et al. 2007).

With previous studies, it is proved that the elevated FOG (fat, oil and grease) loading rates would lead to the fails of anaerobic digestion process, and hinder the sufficient methane production, especially co-digestion of FOG with municipal wastewater sludge (Luostarinen et al. 2009; Wan et al. 2011; Girault et al. 2012; Noutsopoulos et al. 2013; Wang et al. 2013). High concentrations of LCFA also suppress the lipid hydrolysis by anaerobic micro-organisms (Lalman and Bagley 2000; Rinzema et al. 1994) and further limiting their bioconversion into methane. LCFA specifically inhibits the activity of aceticlastic methanogens, hydrogenotrophic methanogens and syntrophic bacteria (Pereira et al. 2005).

FOG loading threshold values that cause a reduction in methane yields, especially during co-digestion with wastewater sludge, range from 0.5 to $2.0 \mathrm{~g} \mathrm{VS} \mathrm{L}^{-1}$ days $^{-1}$ (Silvestre et al. 2011). Some of previous studies have proved the biomass adaptation was important for stable FOG digestion with municipal wastewater sludge (Silva et al. 2014). The dynamic of microbial communities and the relationship between the microbial community structure and LCFA conversion efficiency have been previously studied in reactors with co-digestion of FOG with other sources (Ziels et al. 2016).

As is known FOG is neither easily treated by conventional method, nor decomposed biologically, which can be attributed to their inherent tendency and capability to form insoluble aggregates and float on the surface of water (Stoll and Gupta 1997). The stability of FOG AD has become the barriers in practical application. The effect of organic loading rate (OLR) on the microbial community dynamics using waste cooking oil skimmed from food waste as the only AD carbon source has received little attention. To better understand the loading threshold values of FOG, microbial mechanisms research of unstable fermentation during anaerobic digestion of waste cooking oil is imperative.

In this paper, we start an $A D$ reactor with 100-day hydraulic retention time (HRT) at low concentrations of FOG $\left(0.5 \mathrm{~g} \mathrm{VS} \mathrm{L}^{-1}\right.$ days $\left.^{-1}\right)$ for 50 days to acclimatize the inoculum. After the start stage, AD reactor run at HRT of 10-day with the OLR heightened in a step-by-step mode. For each loading segment, the methane production is described through testing the methane yield and VFA concentration. The aim of this study was to elucidate the effect of OLR on the biomethane production and microbial community structure during different phase, and propose the most suitable FOG loadings for waste cooking oil-based anaerobic digestion.

\section{Materials and methods}

\section{Substrates and inoculum}

Waste food (WF) was collected from a restaurant located in ChengDu, China. Waste cooking oil (hereby referred to as FOG) was separated using an oil remover, then precipitated FOG for $48 \mathrm{~h}$ to make particulate precipitation, after that filtered to remove bubbles and solid and then stored at $4{ }^{\circ} \mathrm{C}$. The pretreated FOG with density of $0.928 \mathrm{~g} \mathrm{~mL}^{-1}$ were used as the raw material for anaerobic fermentation. The seed sludge was obtained from an anaerobic digester that was used for treating WF at $35^{\circ} \mathrm{C}$. Before being loaded into reactors, the sludge was filtered through a $2-\mathrm{mm}$ stainless steel sieve. The volatile solids (VS) concentration of sludge was $20 \pm 1 \mathrm{~g} \mathrm{VS} \mathrm{L}^{-1}$.

\section{Reactor operations}

A semi-continuous complete anaerobic digester $(3 \mathrm{~L}$ working volume) functioning at $35 \pm 1{ }^{\circ} \mathrm{C}$ was used in this study. The digester was set to mix the organic waste with its axial flow impellers at 250-300 rpm. The initially loaded anaerobic sludge in the reactor was diluted with tap water to reach $5.4 \pm 0.2 \mathrm{~g} \mathrm{VS} \mathrm{L}^{-1}$. The reactor was fed once a day with 100-day HRT at the start stage, then the loading rate was increased step-by-step and the hydraulic retention time (HRT) remain 10-day throughout the experiment, as shown in Table 1.

Digester performance was monitored by calculating the daily biogas production, methane content, effluent volatile fatty acids (VFA), total solids (TS) and volatile solid content (VS). The biogas produced was determined with

\begin{tabular}{|c|c|c|c|c|}
\hline Days & $\begin{array}{l}\text { FOG VSLR } \\
\left(\mathrm{g} \mathrm{VS} \mathrm{L}^{-1} \text { day }^{-1}\right)\end{array}$ & HRT (day) & $\begin{array}{l}\text { FOG daily } \\
\text { added (g) }\end{array}$ & $\begin{array}{l}\text { Water daily } \\
\text { added (mL) }\end{array}$ \\
\hline $0-50$ & $0.5(0.05)$ & 100 & 1.5 & 28.5 \\
\hline $51-61$ & $0.5(0.05)$ & 10 & 1.5 & 298.5 \\
\hline $62-77$ & $1.0(0.1)$ & 10 & 3.0 & 297 \\
\hline $78-91$ & $1.5(0.1)$ & 10 & 4.5 & 295.5 \\
\hline $92-103$ & $2.0(0.1)$ & 10 & 6.0 & 294 \\
\hline 104-113 & 0 & 10 & 0 & 300 \\
\hline
\end{tabular}

Values in parentheses indicate one standard deviation 
a wet gas meter and collected in foiled aluminum bags (Delin, China). TS and VS contents of the sludge were determined according to the standard methods (AWWA et al. 1995).

The biogas composition (methane, carbon dioxide, and nitrogen) was analyzed daily using a gas chromatography (GC-2010, Shimadzu, Japan) equipped with a thermal conductivity detector, which used hydrogen as the carrier gas. VFA fractions such as acetate, propionate and butyrate were analyzed by chromatography $(7820 \mathrm{~A}$, Agilent, Palo Alto, CA, USA). The analysis was done using a capillary column (DB-FFAP, Agilent, Palo Alto, CA, USA) equipped with a flame ionization detector.

\section{DNA extraction and polymerase chain reaction (PCR)}

Digester biomass samples were collected for DNA analysis on the 51st, 61st, 68th, 78th, 82nd, 92nd, 98th, 104th and 113th day. $20 \mathrm{~mL}$ of digester sludge were transferred into sterilized $50-\mathrm{mL}$ tubes. Then samples were centrifuged immediately at $10,000 \times g$ for $20 \mathrm{~min}$ at $4{ }^{\circ} \mathrm{C}$. The supernatant was decanted and was immediately frozen at $-80{ }^{\circ} \mathrm{C}$. Total DNA was extracted from each sample using E.Z.N.A. ${ }^{\circledR}$ soil DNA Kit (Omega Bio-tech, Norcross, GA, USA). The V3-V4 hypervariable regions of the 16S rRNA genes of the extracted DNA samples were amplified in a PCR system (GeneAmp 9700, ABI, Foster City, CA, USA) with primers 338F and 806R for bacteria and $344 \mathrm{~F}$ and $915 \mathrm{R}$ for archaea.

The PCR reactions were conducted using the following steps: 3 min of denaturation at $95^{\circ} \mathrm{C} ; 27$ cycles of $30 \mathrm{~s}$ at $95{ }^{\circ} \mathrm{C}, 30 \mathrm{~s}$ for annealing at $55^{\circ} \mathrm{C}$, and $45 \mathrm{~s}$ for elongation at $72{ }^{\circ} \mathrm{C}$, and a final extension at $72{ }^{\circ} \mathrm{C}$ for $10 \mathrm{~min}$. The extracted DNA was further purified using the Kit (Axygen Biosciences, Union City, CA, USA), as per the manufacturer's protocols.

\section{High throughput amplicon sequencing of 16S rDNA genes and analysis}

The PCR products were sequenced with Illumina MisSeq platform in Majorbio Bio-Pharm Technology Co. Ltd., (Shanghai, China) A total of 383,117 quality-filtered reads were obtained from the Illumina sequencing of bacterial 16S rDNA gene amplicons (8 samples), while a total of 355,640 quality-filtered reads were obtained from sequencing of archaeal 16S rDNA gene amplicons (8 samples). The raw data were deposited into the NCBI Sequence Read Archive (SRA) database (BioProjectPRJNA386213).

\section{Statistical analysis}

Each experiment was repeated three times using duplicate samples. Statistical comparisons were made by the analysis of variance (ANOVA). Differences were considered significant when the $\mathrm{p}$-values were $<0.05$.

\section{Results}

Bioreactor performance

Semi-continuous anaerobic digestion of FOG started at low OLR (0.5 g VS $\mathrm{L}^{-1}$ days $\left.^{-1}\right)$ for 50 days. SBY/SMY profiles of the added FOG, VS/volumetric biogas/methane production rate, VFAs and methane concentration from 51st to 114th day were shown in Fig. 1. Performance oscillations in terms of SBY/SMY and VFAs concentrations were observed in the reactor at each elevation of OLR, thus implying internal adaptation of microbial communities.

At the end of the acclimation phase, elevation of OLR resulted in a slight increase in the average SMY or performance at OLR of $1.5 \mathrm{~g} \mathrm{VS} \mathrm{L}^{-1}$ days $^{-1}$. However, the performance was found to decrease when the OLR was added up to $2.0 \mathrm{~g} \mathrm{VS} \mathrm{L}^{-1}$ days $^{-1}$. The calculated values of average SBY and SMY at OLR $1.0 \mathrm{~g} \mathrm{VS} \mathrm{L}^{-1}$ days $^{-1}$ were $1.44 \pm 0.15$, and $0.98 \pm 0.11 \mathrm{~L} \mathrm{~g} \mathrm{VS}^{-1}$ days $^{-1}$ (average of the data obtained from 61st to 77 th day). Subsequently, at OLR $1.5 \mathrm{~g} \mathrm{VS} \mathrm{L}^{-1}$ days $^{-1}$, the average SBY and SMY were found to be $1.64 \pm 0.11$ and $0.78 \pm 0.06 \mathrm{~L} \mathrm{~g} \mathrm{VS}^{-1}$ days ${ }^{-1}$ (average of the data obtained from 78th to 88th day), whereas the average SBY and SMY values obtained at OLR of $2.0 \mathrm{~g} \mathrm{VS} \mathrm{L}^{-1}$ days $^{-1}$ were $0.85 \pm 0.16$, and $0.56 \pm 0.10 \mathrm{~L} \mathrm{~g} \mathrm{VS}^{-1}$ days $^{-1}$ (average of the data obtained from day 89th to 99th).

The VFA concentration profiles indicated that the reactor maintained a fluctuating state during OLR elevation, as shown in Fig. 1c. Furthermore, at OLR $1.0 \mathrm{~g} \mathrm{VS} \mathrm{L}^{-1}$ days $^{-1}$, VFA concentration was found to be less than $300 \mathrm{mg} \mathrm{L}^{-1}$, which indicated good adaptation to the first elevation in OLR. The VFA concentration further rose to $600 \mathrm{mg} \mathrm{L}^{-1}$ as the OLR was increased to $1.5 \mathrm{~g} \mathrm{VS} \mathrm{L}^{-1}$ days $^{-1}$, after which it quickly fell to $150 \mathrm{mg} \mathrm{L}^{-1}$. Interestingly, the VFA concentration again increased to $400 \mathrm{mg} \mathrm{L}^{-1}$, which indicated that accumulation of VFA in the reactor showed no influence on the fermentation balance. Once the OLR increased to $2.0 \mathrm{~g} \mathrm{VS} \mathrm{L}^{-1}$ days $^{-1}$, VFA concentration was limited to $400 \mathrm{mg} \mathrm{L}^{-1}$, and then rapidly increased to $700 \mathrm{mg} \mathrm{L}^{-1}$, thereby bringing down the biogas production in an abrupt manner. VFA concentration was gradually reduced to $400 \mathrm{mg} \mathrm{L}^{-1}$ by the 113th day when no organic waste materials were further fed.

\section{Bacterial community dynamics as revealed by high-throughput pyrosequencing}

High-throughput pyrosequencing is one of the most widely used methods of investigation of microbial community structure and dynamics. In the present study, 


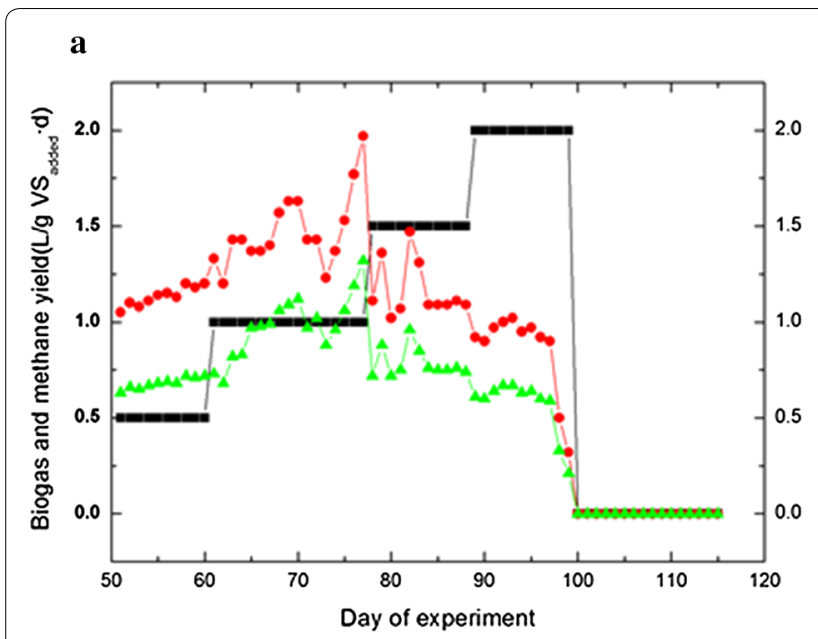

c

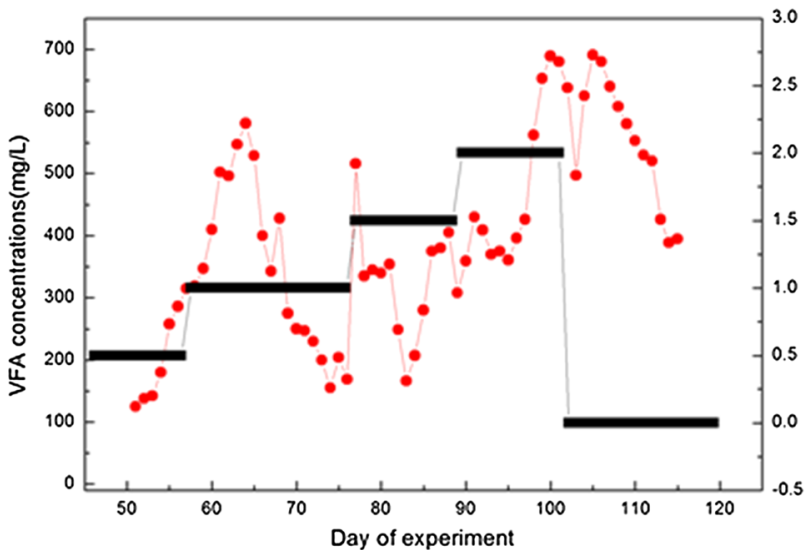

b

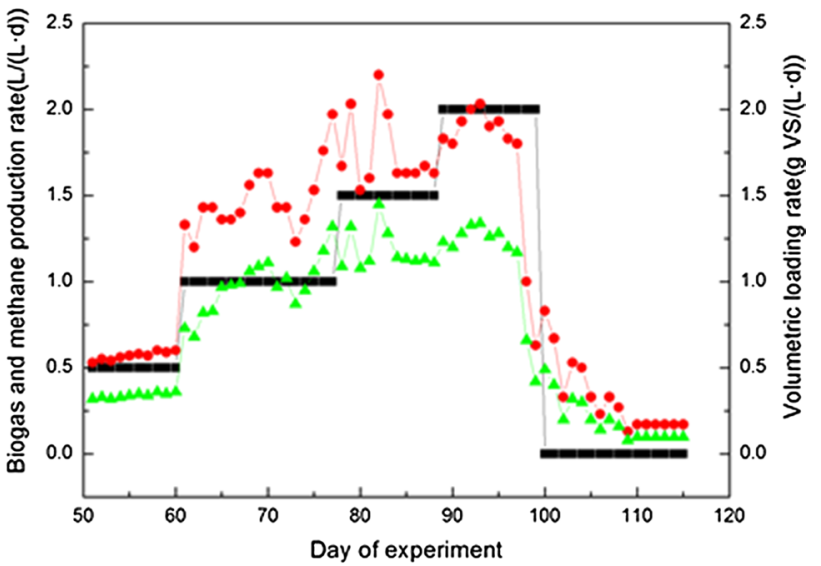

d

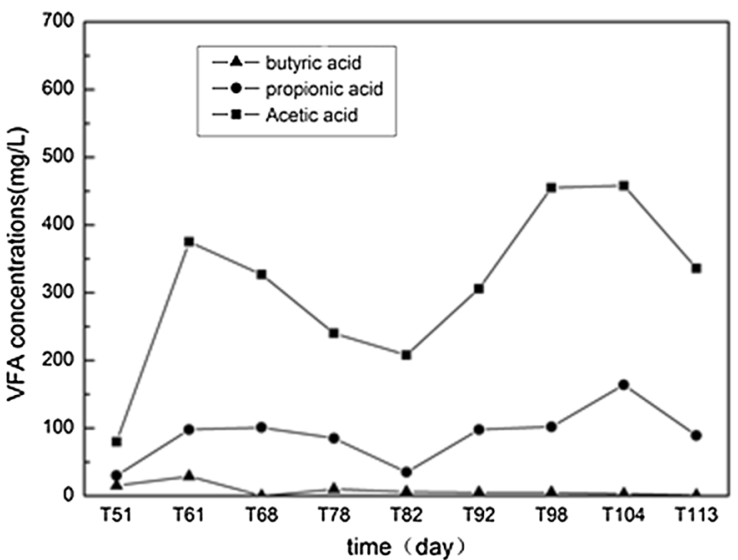

Fig. 1 Evolution of biogas/methane yield (a), volumetric biogas/methane production rate (b) and volatile fatty acids (VFAs) (c, d) in reactors with elevated OLR

the samples collected on day 51st, 61st, 68th, 78th, 82nd, 92nd, 98th, 104th and 113th (which were denoted as T51, T61, T68, T78, T82, T92, T98, T104 and T113, respectively) were used for analysis. The results obtained from the analysis of various diversity estimators viz. Chao1,
Shannon index, ACE, Simpson index and Good's coverage of sequencing for each sample are shown in Table 2. The coverage of sequencing for the all the samples were found to be more than 0.99 , which integrated with higher ACE, Chao1 and Shannon index values. These values

Table 2 Statistics analysis of the bacterial 16S rRNA gene libraries obtained from the pyrosequencing

\begin{tabular}{|c|c|c|c|c|c|c|}
\hline Sample ID & ACE & Chao1 & Coverage & Shannon & Simpson & Sequences \\
\hline T51 & 306 & 311 & 0.99 & 3.16 & 0.09 & 36739 \\
\hline T61 & 330 & 334 & 0.99 & 3.92 & 0.04 & 34919 \\
\hline T68 & 329 & 330 & 0.99 & 3.76 & 0.04 & 28493 \\
\hline T78 & 317 & 322 & 0.99 & 3.60 & 0.06 & 41490 \\
\hline T82 & 323 & 318 & 0.99 & 3.47 & 0.05 & 28646 \\
\hline T92 & 272 & 392 & 0.99 & 2.39 & 0.21 & 39491 \\
\hline T98 & 259 & 259 & 0.99 & 2.82 & 0.14 & 29366 \\
\hline T104 & 270 & 260 & 0.99 & 2.13 & 0.31 & 36147 \\
\hline T113 & 304 & 310 & 0.99 & 3.03 & 0.09 & 42475 \\
\hline
\end{tabular}

All values were calculated at 0.03 distance limit 
jointly implied the presence of highly diverse bacterial communities in T51, T61, T68, T78, T82 and T113. The high diversity of microbial communities can be regarded as an augment for functional redundancy, at least in terms of ecology (Finlay et al. 1997). These values also showed the low diverse bacterial communities at T92 and T98 caused by load shock, that presumably means the change of microbial communities abundance and reduction of stability.

Distribution of sequences at the phylum level in each sample was shown in Fig. 2. The sequencing results indicated that there were 10 phyla in total, each with a relative abundance higher than $1 \%$ in at least one sample. The minor phyla were grouped into a separate group. Firmicutes was the most dominant phylum that appeared in the entire process, while Synergistetes was the secondary. Chloroflexi and Bacteroidetes possibly playing a necessary role in the community dynamics appeared throughout the process with lower percentages.

To further integrate the dynamics of bacterial communities, the sequencing data was deconstructed at the subdivision level. Therefore, the relative abundance of each genus in all the samples was calculated. The top 100 genera were detected, among which 147 genera with a proportion higher than $0.5 \%$ was screened as the abundant genera (Fig. 3). Other genera were considered as minor groups. The sequence distribution at the genus level in each sample are shown in Fig. 3. Anaerovibrio, Syntrophomonas, Aminobacterium, Gelria, Synergistaceae, Longilinea and Ruminococcaceae were the major genera that appeared during the entire process. Anaerovibrio emerged as the most dominant genus with increasing organic loading rate (82nd to 113th day) and possessed high tolerance throughout the process. On the other hand, the proportions of Anaerovibrio and Aminobacterium increased initially and then decreased with elevation of OLR rates. The proportion of Longilinea decreased, while Ruminococcaceae increased with time.

\section{Dynamics of methanogen communities}

16S rDNA gene targeted high throughput pyrosequencing was used to reveal the archaeal community dynamics of the reactor samples. It was shown that most of the sequence reads were identified as methanogens (more than $98 \%$ in each individual sample). The results obtained from the application of diversity estimators of Chao 1, ACE and Shannon index are shown in Table 2 and the sequence distribution at the genus level is shown in Fig. 4. It was indicated that the diversity of bacterial community was much higher than archaeal community, which was caused by the inherent low abundance and diversity of the archaeal community.

It was observed that Methanosaeta was the most dominant genus, the relative concentration of which decreased

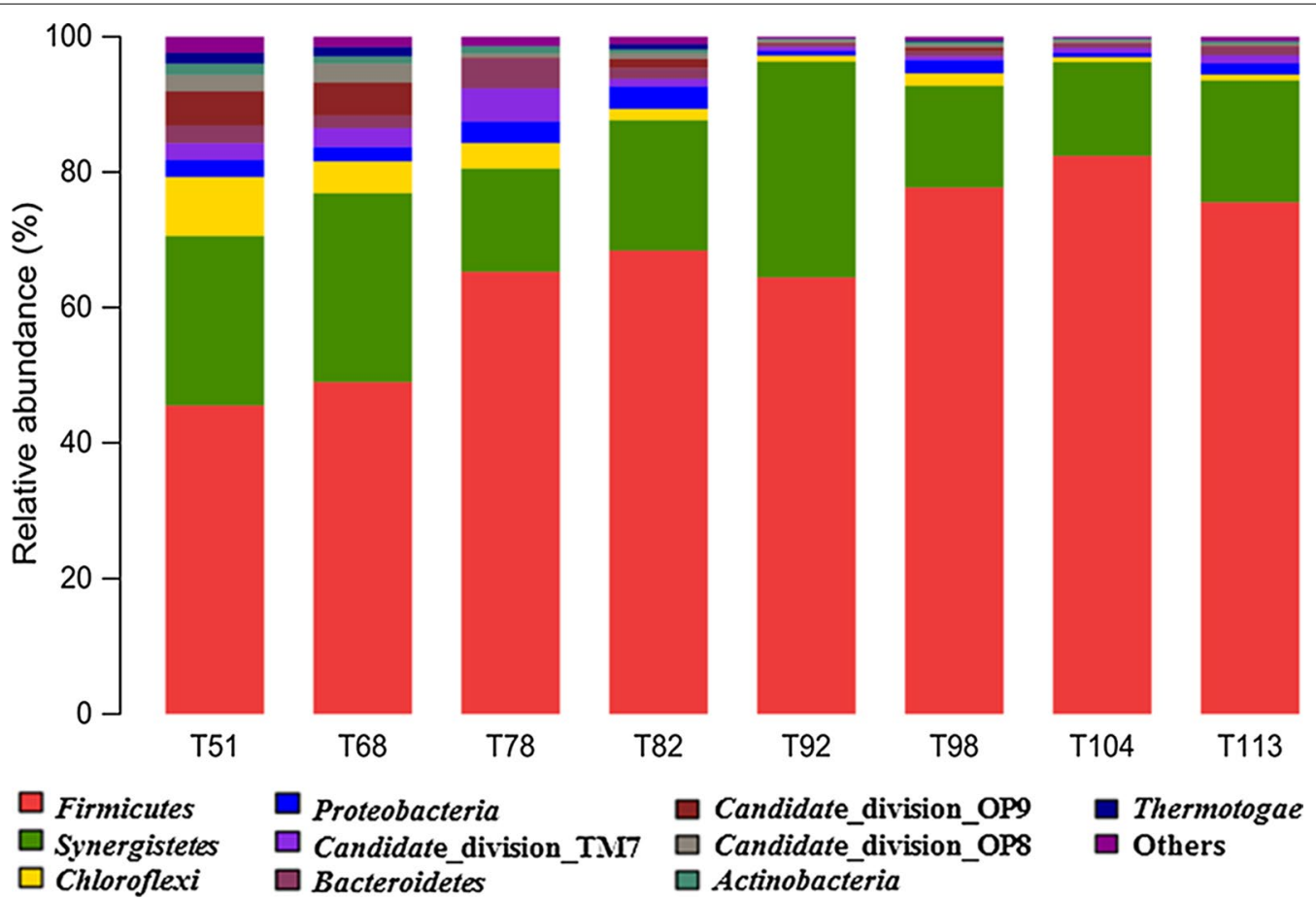

Fig. 2 Taxonomic compositions of bacterial communities at phylum level in each sample retrieved from pyrosequencing. The number in the sample names represented the day when sampling occurred 


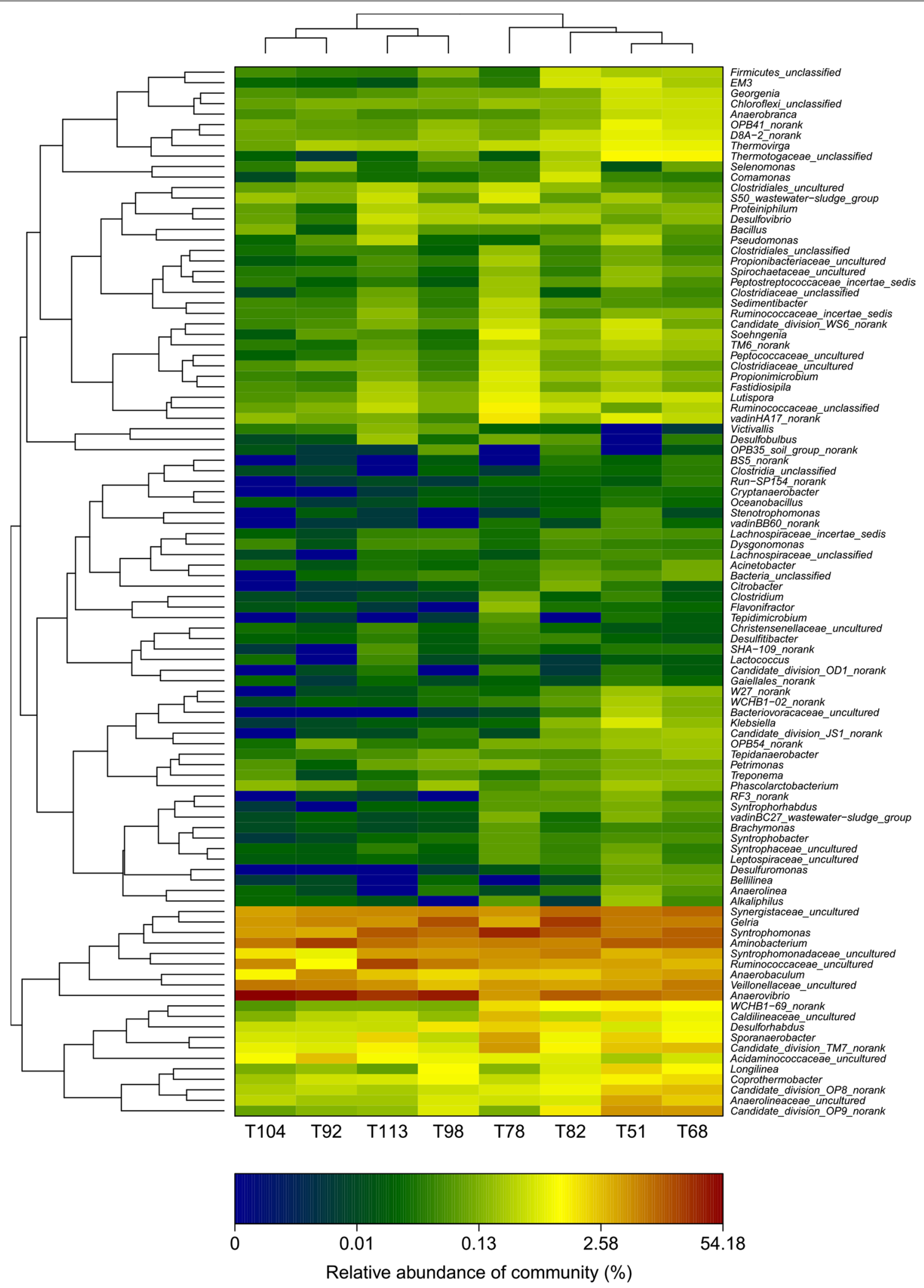

Fig. 3 Hierarchical cluster analysis of microbial communities among the 8 samples. The Y-axis is the clustering of the top 100 abundant genus. Different samples were clustered based on complete linkage method 

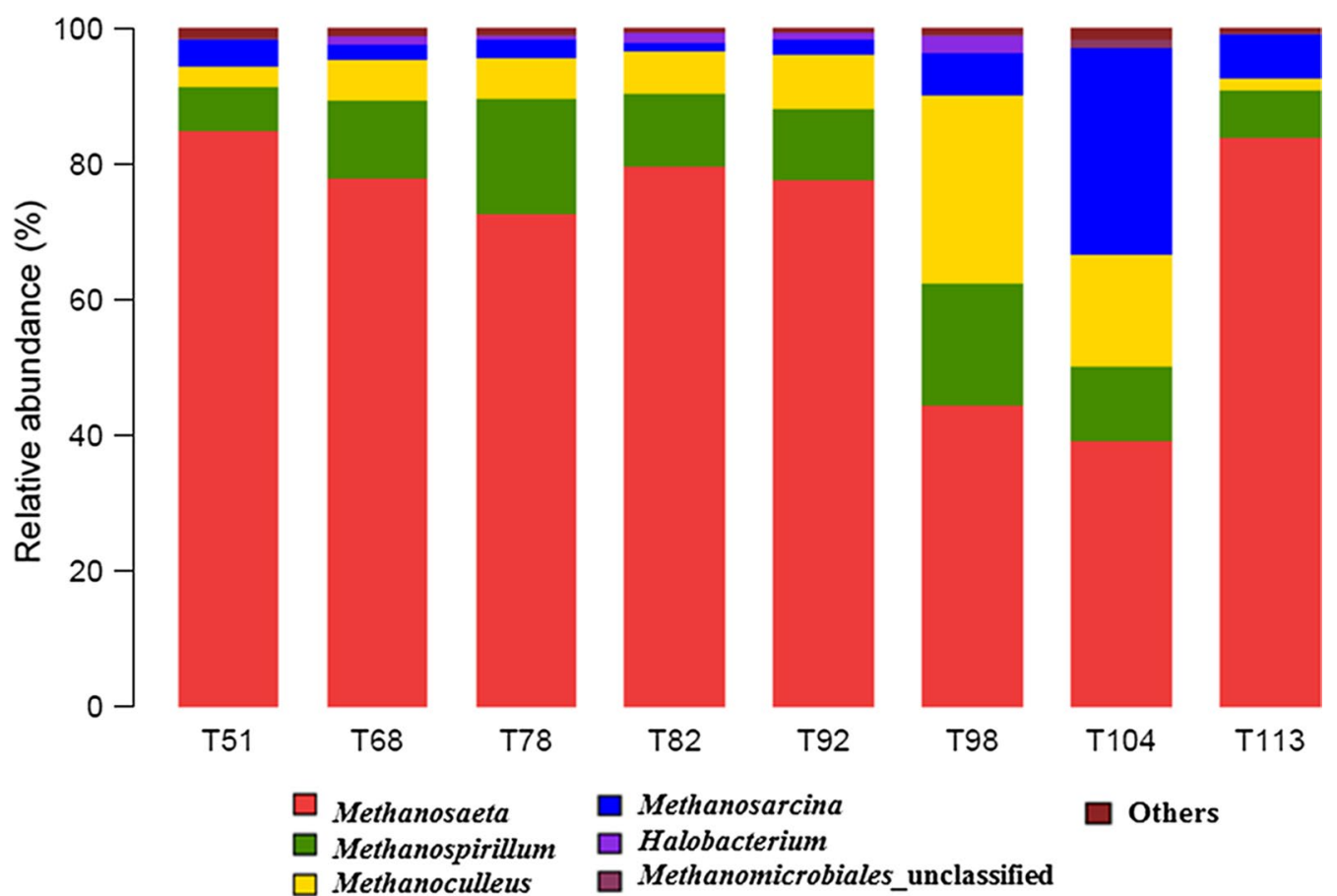

\section{Methanosarcina \\ Halobacterium \\ Methanomicrobiales_unclassified}

Fig. 4 Taxonomic compositions of methanogens at the genus level in each sample retrieved from pyrosequencing. The sample was named as in Fig. 2

from $82 \%$ on day 51 to $45 \%$ by 98 st day. On the other hand, the relative concentration of Methanosarcina was found to increase from $\sim 4$ to $30 \%$ by day 104 . These results indicate that the acetoclastic methanogens were the most dominant trophic type of methanogens present in the digester. Methanosaeta, the only known specialized acetoclastic methanogen (Garcia et al. 2000), are known to have lower maximum growth rate on acetate, but they are known to possess higher affinity for acetate as compared to the Methanosarcina (Conklin et al. 2006). It was thus suggested that higher acetate concentrations in the growth environment would favourable for the Methanosarcina growth, while lower concentrations would favourable for the Methanosaeta growth.

On 104th day, as the accumulated VFA increased to $700 \mathrm{mg} \mathrm{L}^{-1}$, the relative concentration of genus Methanosarcina was also found to increase to $30.45 \%$. It was reported that Methanosarcina spp. grow in aggregates and form irregular cell clumps, which may result in increased tolerance against high concentrations of toxic agents (Calli et al. 2005). Furthermore, Methanosarcina are known to generate methane from acetate, methanol, monomethylamine, dimethylamine, trimethylamine, $\mathrm{H}_{2}$ / $\mathrm{CO}_{2}$ and $\mathrm{CO}$ which are both acetoclastic and hydrogenotrophic (Conklin et al. 2006). Flexibility in metabolism and the special morphological characteristics of the members of Methanosarcina enable them to outcompete other methanogens during the acclimation phase. Other methanogens that were identified in the study were mostly assigned to genera Methanospirillum and Methanoculleus, indicating that the roles of hydrogenotrophic methanogens in FOG anaerobic digestion reactors are weaker than the acetoclastic methanogens.

\section{Linkage between the dynamics of microbial communities and reactor performances}

Redundancy analysis (RDA) is a kind of sorting method that is based on correspondence analysis. It is mainly used to reflect the relationship between the bacteria and the environmental factors. The data presented in Fig. 5 shows that RDA was used to illustrate the relationships among bacterial community structures, reactor performances (including total VFA, acetate, propionate, palmitic acid) and operational conditions (volumetric organic loading). The fractions of the total variabilities that were illustrated using the RDA models were 45.15 and $59.35 \%$ for the bacteria and archaea OUT abundance datasets, respectively.

Redundancy analysis (Fig. 5) revealed that the TOP 10 archaeal communities in the initial stages of fermentation (T68, T78, T82, T92) were associated with total VFA, acetate, palmitic acid and volumetric organic loading rate (OLR). On the other hand, TOP 10 bacterial communities found in the later stages of fermentation (T98, T104, 

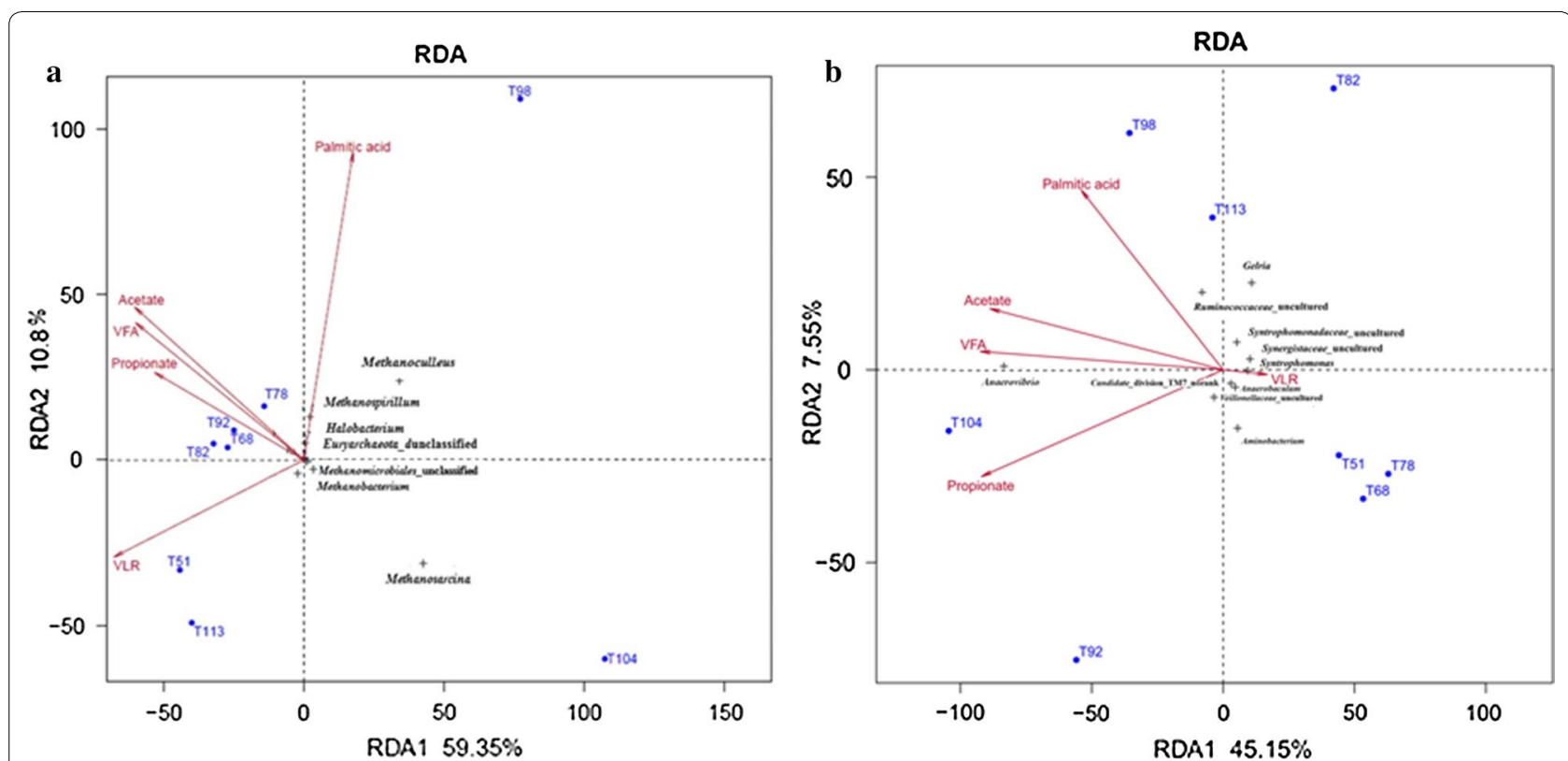

Fig. 5 Triplots of RDA ordination diagrams of TOP10 archaeal community (a) and TOP10 bacterial community (b) with total VFA, acetate, propionate, palmitic acid and volumetric organic loading rate (here $V L R=O L R$ )

T113) were correlated with total VFA, acetate, propionate and palmitic acid. It was suggested that the effects of OLR were slightly on the archaeal communities (Fig. 5a), but it had profound effects on the bacterial communities (Fig. 5b). Palmitic acid contributed to the variability in bacterial community to some extent but not very significantly.

\section{Discussion}

FOG is neither easily treated by conventional method, nor decomposed biologically (Stoll and Gupta 1997). FOG co-digestion with other waste materials was a feasible way to alleviate LCFA suppresses, but loading threshold values still was a barrier during FOG AD. FOG, as an $\mathrm{AD}$ material, is widely used for co-digestion with various other organic wastes (such as sludge and livestock manure). It has earlier been observed that high FOG loading rates cause technical discrepancies in the process of fermentation and even delay process recovery, especially due to the inhibitory effect of LCFAs. Hence, previous studies about the functional role and dynamics of the various microbial species that are involved in the LCFA $\beta$-oxidation in anaerobic reactors have been done (Table 3).

As discussed previously, LCFA inhibition exists in the anaerobic reactors and is quite difficult to be resolved. However, co-digestion of FOG with other feedstock is considered an effective method to resolve this problem. The results of co-digesting FOG with municipal sludge indicated that the relative concentration of the syntrophic genus Syntrophomonas increased to $\sim 15 \%$ of the total bacterial community in the reactor (Ziels et al. 2016).

In this study, FOG degradation-related bacteria such as the hydrolytic bacteria, syntrophic bacteria and methanogenic archaea were investigated. Furthermore, the correspondence analysis of environmental factors with microorganism community was also elucidated. The results of the present study indicated that with the elevation of the loading rates, the relative concentration of the members of genus Anaerovibrio (lipid hydrolysis bacteria) also increased from 9.3 to $40 \%$, while the relative concentration of the members of genus Syntrophomonas increased to $\sim 29 \%$. The present study also indicated that Methanosaeta and Methanosarcina were the most dominant methanogenic genera and acetate fermentation was the main pathway for methane formation in anaerobic digestion reactors using waste cooking oil as the only carbon source. Additionally, whether OLR inrease had slight influence on the acetate fermentation pathway.

When the FOG loading rate was added to $2.0 \mathrm{~g} \mathrm{VS} \mathrm{L}^{-1}$ days $^{-1}$, it came to the highest value for the proportion of Anaerovibrio (Fig. 6). Anaerovibrio is known as a fat decomposer that could hydrolyze triglycerides to produce glycerol and fatty acids. It could thus be concluded that the fat hydrolysis bacteria Anaerovibrio plays a key role in FOG anaerobic digestion.

Syntrophomonas, Synergistaceae and Anaerovibrio were the most dominant genera in the low organic 
Table 3 Characterization of microbial community of AD with LCFA or FOG

\begin{tabular}{|c|c|c|c|c|c|}
\hline References & Substrate & AD pattern & Method & $\begin{array}{l}\text { Methanogenic } \\
\text { archaea community }\end{array}$ & Bacterial community \\
\hline $\begin{array}{l}\text { Shigematsu et al. } \\
(2006)\end{array}$ & Oleic and palmitic acids & $\begin{array}{l}\text { Semi-continuous, CSTR, } \\
37^{\circ} \mathrm{C}\end{array}$ & DGGE & $\begin{array}{l}\text { Dominant genera } \\
\text { Methanosaeta } \\
\text { Methanosarcina } \\
\text { Methanospirillum }\end{array}$ & $\begin{array}{l}\text { Dominant phyla } \\
\text { Bacteroidetes } \\
\text { Spirochaetes syn- } \\
\text { trophomonadaceae }\end{array}$ \\
\hline Sousa et al. (2007b) & $\begin{array}{l}\text { MixLCFA, Palmitate } \\
\text { 32-48\%; Myristate } \\
\text { 11-15\%; oleate } \\
\text { 23-26\% }\end{array}$ & Batch, $35^{\circ} \mathrm{C}$ & DGGE & $\begin{array}{l}\text { Dominant genera } \\
\text { Methanosaeta } \\
\text { Methanosarcina }\end{array}$ & $\begin{array}{l}\text { Dominant phyla(80\%) } \\
\text { Clostridiaceae }\end{array}$ \\
\hline Baserba et al. (2012) & Oleate & $\begin{array}{l}\text { Semi-continuous, CSTR, } \\
55^{\circ} \mathrm{C}\end{array}$ & DGGE & $\begin{array}{l}\text { Dominant genera } \\
\text { Methanosarcina } \\
\text { Methanococcus }\end{array}$ & $\begin{array}{l}\text { Dominant phyla } \\
\text { Firmicutes } \\
\text { Bacteroidetes } \\
\text { Proteobacteria } \\
\text { Thermotogae }\end{array}$ \\
\hline Yang et al. (2016) & $\begin{array}{l}\text { FOG and sewage } \\
\text { sludge }\end{array}$ & $\begin{array}{l}\text { Semi-continuous, CSTR, } \\
35^{\circ} \mathrm{C}\end{array}$ & $\begin{array}{l}\text { High-throughput } \\
\text { pyrosequencing }\end{array}$ & $\begin{array}{l}\text { Dominant genera } \\
\text { Methanosarcinales } \\
\quad(11.7 \%) \\
\text { Methanosaeta }(13.2 \%)\end{array}$ & $\begin{array}{l}\text { Dominant phyla: } \\
\text { Actinobacteria (28.4\%) } \\
\text { Firmicutes (22.9\%) } \\
\text { Bacteroidetes (12.5\%) }\end{array}$ \\
\hline Ziels et al. (2016) & $\begin{array}{l}\text { FOG and municipal } \\
\text { sludge }\end{array}$ & $\begin{array}{l}\text { Semi-continuous, CSTR, } \\
35^{\circ} \mathrm{C}\end{array}$ & $\begin{array}{l}\text { High-throughput } \\
\text { pyrosequencing } \\
\text { +qPCR }\end{array}$ & $\begin{array}{l}\text { Dominant genera } \\
\text { Methanosaeta } \\
(23 \rightarrow 45 \%) \\
\text { Methanospirillum } \\
(1.3 \rightarrow 34 \%) \\
\text { Methanosphaera } \\
(0 \rightarrow 7 \%)\end{array}$ & $\begin{array}{l}\text { Dominant genera } \\
\text { Syntrophomonas } \\
(1.2 \rightarrow 9.0 \%) \\
\text { Gelria }\end{array}$ \\
\hline Present study & FOG solely & $\begin{array}{l}\text { Semi-continuous, CSTR, } \\
35^{\circ} \mathrm{C}\end{array}$ & $\begin{array}{l}\text { High-throughput } \\
\text { pyrosequencing }\end{array}$ & $\begin{array}{l}\text { Dominant genera } \\
\text { Methanosaeta } \\
(82 \rightarrow 45 \rightarrow 82 \%) \\
\text { Methanoculleus } \\
(4 \rightarrow 25 \rightarrow 2 \%) \\
\text { Methanospirillum } \\
(7 \rightarrow 18 \rightarrow 8 \%) \\
\text { Methanosarcina } \\
(4 \rightarrow 40 \%)\end{array}$ & $\begin{array}{l}\text { Dominant genera } \\
\text { Syntrophomonas } \\
\quad(12 \rightarrow 35 \%) \\
\text { Anaerovibrio } \\
\quad(10 \rightarrow 40 \rightarrow 20 \%)\end{array}$ \\
\hline
\end{tabular}

loading phase (51st to 82nd day), and decreased when the organic loading rate increased (Fig. 6). The bacterial sequence library indicated that the concentration of Syntrophomonas increased from $7.8 \%$ in the initial phase to $29 \%$ by day 78 as the OLR increased. The concentration again went down to about $9 \%$ as the OLR reached $2.0 \mathrm{~g} \mathrm{VS} \mathrm{L}^{-1}$ days $^{-1}$ (Fig. 6). The relative abundance of $S y$ ntrophomonadaceae_(uncultured) increased from $\sim 3$ to $7.3 \%$ by day 82 , and then decreased to about $4.5 \%$ as the OLR reached $2.0 \mathrm{~g} \mathrm{VS} \mathrm{L}^{-1}$ days $^{-1}$. Syntrophomonadaceae and Syntrophaceae, the members of syntrophic bacterial families, are well known for their LCFA $\beta$-oxidation properties (McInerney et al. 1981; Hatamoto et al. 2007; Sousa et al. 2007a). It can thus be implied that the members of these two syntrophic bacterial genera also play significant roles in anaerobic mesophilic digestion. However, the study indicated that their properties get compromised at high loading rates.

Synergistaceae_uncultured was found to remain at $6-10 \%$ as the loading rates increased. The members of Synergistaceae are known to belong to "Synergistes".
The species of this genus have been detected in samples which were collected from different environmental sources, such as anaerobic digesters, waste water, petroleum reservoirs, and soil (Sonia et al. 2007). The Synergistaceae was considered to play an intermediate role in the consortia, especially because they can use the amino acids made available from the breakdown of proteins by other organisms and provide short-chain fatty acids and sulphate for terminal degraders, such as methanogens and sulphate-reducing bacteria.

The present study suggested that a stable biogas production was obtained at an organic loading rate of 0.5$1.5 \mathrm{~g} \mathrm{VS} \mathrm{L}^{-1}$ days $^{-1}$ using waste cooking oil skimmed from food waste as the only AD carbon source with a HTR of 10 days. Upon elevation of OLR, the genus Methanosaeta (acetoclastic methanogens) became the most dominant methanogen in the system. Syntrophic LCFAdegrading bacteria such as genera Syntrophomona and Synergistaceae were found to persist during the total AD process and hence resulted in better performance. The proportions of Anaerovibrio (lipids-degrading bacteria) 


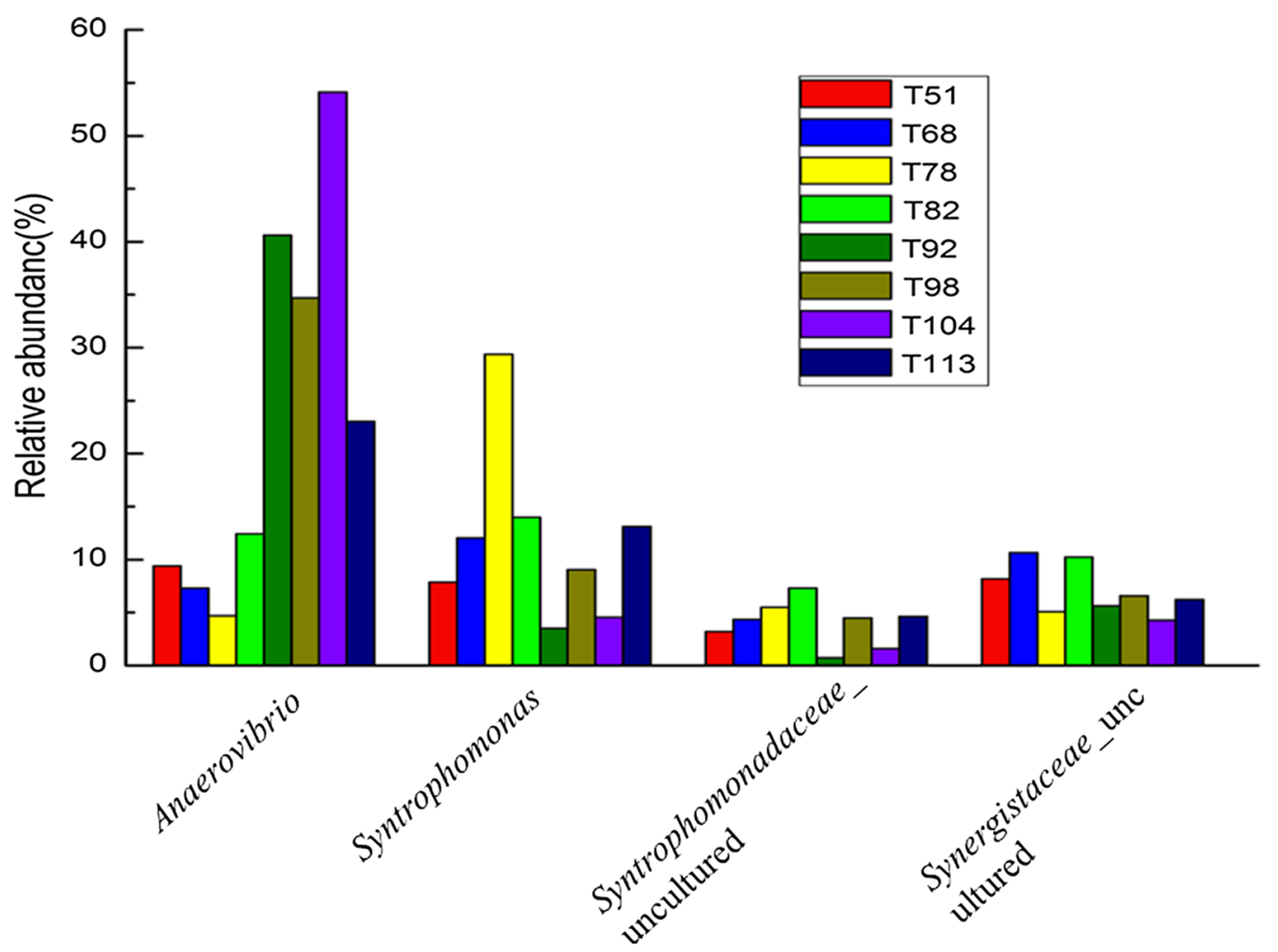

Fig. 6 Relative abundance of the lipolytic bacteria and three mainly syntrophy bacteria at the time of 51st, 68th, 78th, 82nd, 92nd, 98th, 104th and 113th days

were also found to increase up to $40 \%$ with OLR elevation. The effects of OLR on the bacterial community dynamics were found to be highly significant, as compared with that on the archaeal communities.

\section{Abbreviations}

FW: food waste; LCFA: long chain fatty acids; AD: anaerobic digestion; FOG: fats, oils and grease; OLR: organic loading rate; SBY: specific biogas yield; SMY: specific methane yield; VFA: volatile fatty acids; TS: total solids; VS: volatile solid content; HRT: hydraulic retention time; RDA: redundancy analysis.

\section{Authors' contributions}

$\mathrm{JH}$ and YD designed the work; $\mathrm{JH}, \mathrm{XW}$ and $\mathrm{QL}$ performed the experiments and analyzed the data; $X B Y, X L, Y F Z$, and $Y D$ reviewed and edited the manuscript; $\mathrm{JH}$ and $\mathrm{XW}$ wrote the manuscript. All authors read and approved the final manuscript.

\section{Acknowledgements}

We are grateful to the Key Laboratory of Rural Renewable Energy Development and Application of the Ministry of Agriculture of China for technical assistance.

\section{Competing interests}

The authors declare that they have no competing interests.

\section{Availability of data and materials}

Not applicable.

Ethics approval and consent to participate Not applicable.

\section{Funding}

This work was accomplished with the financial support of the National High Technology. Research and Development Program of China (2013AA10280502), the Special Fund for Agro-scientific Research in the Public Interest of China (201303099-1), AND the Funding for Basic Scientific Research of Biogas Institute of Ministry (MOA, China) (1610012016025).

\section{Publisher's Note}

Springer Nature remains neutral with regard to jurisdictional claims in published maps and institutional affiliations.

Received: 16 March 2018 Accepted: 27 May 2018

Published online: 01 June 2018

\section{References}

Agency, U.S.E.P (2012) Municipal solid waste generation, recycling, and disposal in the United States: facts and figures for 2012. Agency U.S.E.P, Washington DC

Angelidaki I, Ahring BK (1992) Effects of free long-chain fatty acids on thermophilic anaerobic digestion. Appl Microbiol Biotechnol 37:808-812

AWWA, APHA, WEF (1995) Standard methods for the examination of water and waste water, 19th edn. American Public Health Association/American Water Works Association/Water Environment Federation, Washington

Baserba MG, Angelidaki I, Karakashev D (2012) Effect of continuous oleate addition on microbial communities involved in anaerobic digestion process. Bioresour Technol 106:74-81

Calli B, Mertoglu B, Inanc B, Yenigun O (2005) Community changes during startup in methanogenic bioreactors exposed to increasing levels of ammonia. Environ Technol 26(1):85-91 
Christ O, Wilderer PA, Angerhöfer R, Faulstich M (2000) Mathematical modeling of the hydrolysis of anaerobic processes. Water Sci Technol 41(3):61-65

Cirne DG, Paloumet X, Bjornsson L, Alves MM, Mattiasson B (2007) Anaerobic digestion of lipid-rich wasted effects of lipid concentration. Renew Energy 32:965-975

Conklin A, Stensel HD, Ferguson J (2006) Growth kinetics and competition between Methanosarcina and Methanosaeta in mesophilic anaerobic digestion. Water Environ Res 78(5):486-496

Dasgupta BV, Mondal MK (2012) Bioenergy conversion of organic fraction of Varanasi municipal solid waste. Energy Proc 14:1931-1938

Davidsson A, Lovstedt C, Jansen JL, Gruvberger C, Aspegren H (2008) Codigestion of grease trap sludge and sewage sludge. Waste Manag 28:986-992

Finlay BJ, Maberly SC, Cooper II (1997) Microbial diversity and ecosystem function. Oikos 80(2):209-213

Garcia JL, Patel BKC, Olivier B (2000) Taxonomic, phylogenetic, and ecological diversity of methanogenic archaea. Anaerobe 6(4):205-226

Girault R, Bridoux G, Nauleau F, Poullain C, Buffet J, Peu P, Sadowski AG, Beline $F$ (2012) Anaerobic co-digestion of waste activated sludge and greasy sludge from flotation process: batch versus CSTR experiments to investigate optimal design. Bioresour Technol 105:1-8

Hanaki K, Matsuo T, Nagase M (1981) Mechanism of inhibition caused by longchain fatty acids in anaerobic digestion process. Biotechnol Bioeng 23:1591-1610

Hatamoto M, Imachi H, Fukayo S, Ohashi A, Harada H (2007) Syntrophomonas palmitatica sp. nov., an anaerobic, syntrophic, long-chain fatty-acidoxidizing bacterium isolated from methanogenic sludge. Int I Syst Evol Microbiol 57:2137-2142

Jackson BE, Bhupathiraju VK, Tanner RS, Woese CR, McInerney MJ (1999) Syntrophus aciditrophicus sp. nov., a new anaerobic bacterium that degrades fatty acids and benzoate in syntrophic association with hydrogen-using microorganisms. Arch Microbiol 171:107-114

Kim JK, Han GH, Oh BR, Chun YN, Eom C, Kim SW (2008) Volumetric scale-up of a three stage fermentation system for food waste treatment. Bioresour Technol 99:4394-4399

Lalman JA, Bagley DM (2000) Anaerobic degradation and inhibitory effects of linoleic acid. Water Res 34:4220-4228

Lin CSK, Pfaltzgraff LA, Herrero-Davila L, Mubofu EB, Abderrahim S, Clark JH, Koutinas AA, Kopsahelis N, Stamatelatou K, Dickson F, Thankappan S, Mohamed Z, Brocklesby R, Luque R (2013) Food waste as a valuable resource for the production of chemicals, materials and fuels. Current situation and global perspective. Energy. Environ Sci 6(2):426-464

Luostarinen S, Luste S, Sillanp M (2009) Increased biogas production at wastewater treatment plants through co-digestion of sewage sludge with grease trap sludge from a meat processing plant. Bioresour Technol 100:79-85

McInerney MJ (1992) The genus Syntrophomonas, and other syntrophic bacteria. Prokaryotes. Springer, NY, pp 2048-2057

McInerney MJ, Bryant MP, Hespell RB, Costerton JW (1981) Syntrophomonas wolfei gen. nov. sp. nov., an anaerobic, syntrophic, fatty acid-oxidizing bacterium. Appl Environ Microbiol 41:1029-1039

Meng Y, Shen F, Yuan H, Zou D, Liu Y, Zhu B, Chufo A, Jaffar M, Li X (2014) Start-up and operation strategies on the liquefied food waste anaerobic digestion and a full-scale case application. Bioprocess Biosyst Eng $37: 2333-2341$
Noutsopoulos C, Mamais D, Antoniou K, Avramides C, Oikonomopoulos P, Fountoulakis I (2013) Anaerobic co-digestion of grease sludge and sewage sludge: the effect of organic loading and grease sludge content. Bioresour Technol 131:452-459

Pereira MA, Pires OC, Mota M, Alves MM (2005) Anaerobic biodegradation of oleic and palmitic acids: evidence of mass transfer limitations caused by long chain fatty acid accumulation onto the anaerobic sludge. Biotechnol Bioeng 92:15-23

Rinzema A, Boone M, Knippenberg K, van Lettinga G (1994) Bactericidal effect of long chain fatty acids in anaerobic digestion. Water Environ Res 66:40-49

Shigematsu T, Tang Y, Mizuno Y, Kawaguchi H, Morimura S, Kida K (2006) Microbial diversity of mesophilic methanogenic consortium that can degrade long-chain fatty acids in chemostat cultivation. J Biosci Bioeng 102:535-544

Silva SA, Cavaleiro AJ, Pereira MA, Stams AJM, Alves MM, Sousa DZ (2014) Long-term acclimation of anaerobic sludges for high-rate methanogenesis from LCFA. Biomass Bioenergy 67:297-303

Silvestre G, Rodríguez-Abalde A, Fern_andez B, Flotats X, Bonmatí A (2011) Biomass adaptation over anaerobic co-digestion of sewage sludge and trapped grease waste. Bioresour Technol 102:6830-6836

Sonia RV, Richard MP, William GW (2007) The division "Synergistes". Anaerobe 13:99-106

Sousa DZ, Smidt H, Alves MM, Stams AJM (2007a) Syntrophomonas zehnderi sp. nov., an anaerobe that degrades long-chain fatty acids in co-culture with Methanobacterium formicicum. Int I Syst Evol Microbiol 57:609-615

Sousa DZ, Pereira MA, Smidt H, Stams AJM, Alves MM (2007b) Molecular assessment of complex microbial communities degrading long chain fatty acids in methanogenic bioreactors. FEMS Microbiol Ecol 60:252-265

Stoll U, Gupta H (1997) Management strategies for oil and grease residues. Waste Manag Res 15:23-32

Sun Y, Wang D, Yan J, Qiao W, Wang W, Zhu T (2014) Effects of lipid concentration on anaerobic co-digestion of municipal biomass wastes. Waste Manage 34:1025-1034

Wan C, Zhou Q, Fu G, LiY (2011) Semi-continuous anaerobic co-digestion of thickened waste activated sludge and fat, oil and grease. Waste Manag 31:1752-1758

Wang L, Aziz TN, de los Reyes FL (2013) Determining the limits of anaerobic codigestion of thickened waste activated sludge with grease interceptor waste. Water Res 47:3835-3844

Wu C, Dong X, Liu X (2007) Syntrophomonas wolfei subsp. Methylbutyratica subsp. nov., and assignment of Syntrophomonas wolfei subsp. saponavida to Syntrophomonas saponavida sp. nov. comb. nov. Syst Appl Microbiol 30:376-380

Yang ZH, Xu R, Zheng Y, Chen T, Zhao LJ, Li M (2016) Characterization of extracellular polymeric substances and microbial diversity in anaerobic co-digestion reactor treated sewage sludge with fat, oil, grease. Bioresour Technol 212:164-173

Zhang C, Xiao G, Peng L, Su H, Tan T (2013) The anaerobic co-digestion of food waste and cattle manure. Bioresour Technol 129:170-176

Ziels RM, Karlsson A, Beck DAC, Ejlertsson J, Yekta SS, Bjorn A, Stensel HD, Svensson BH (2016) Microbial community adaptation influences longchain fatty acid conversion during anaerobic codigestion of fats, oils, and grease with municipal sludge. Water Res 103:372-382 